\title{
THE INFLUENCE OF ABSOLUTE THERMAL INVERSION ON THE RELATIVE HUMIDITY IN THE LOWER TROPOSPHERE
}

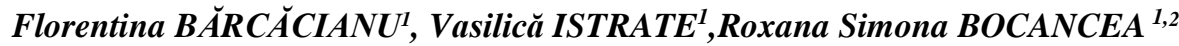

DOI: 10.21163/GT_2016.111.02

\begin{abstract}
:
Increasing temperature values in altitude, as a deviation from normal law, generates stability of air masses. The most typical situations occur outside the Carpathian chain. In particular cases, when the maximum barometric prevail on large European territories, absolute thermal inversions occur, which are characterized by large thickness, intensity, duration and amplitude. These types of thermal inversions block water vapour at lower levels and produce changes in atmospheric moisture regime by forming mists and low stratiform clouds. Geostatistical analysis of this climatic risk phenomena for aeronautical activity was carried out by processing temperature and moisture database from 7 aerological stations and analysis of synoptic maps. The results revealed a strong connection between the two meteorological phenomena, with the highest frequency in winter.
\end{abstract}

Keywords: Radiosoundings, Atmospheric moisture, Low level clouds, Upper thermal inversion

\section{TEORETICAL BACKGROUND}

In the lower layers of the troposphere, occurs the largest variation in elements and weather phenomena, with significant fluctuations in temperature (Bărcăcianu F. et al., 2015) and atmospheric moisture regime, strongly correlated (Wyngaard et all., 1978, Wayan Suparta, 2011). Moisture is critical in geosystem climate, especially in the dynamics of atmospheric circulation. This influences the atmospheres heat budget by moderate heating values (Peixoto \& Oort, 1996), by accumulating the necessary evaporation heat and by releasing it with condensing (Trenberth \& Guillemot, 1998). With increasing altitude the relative humidity drops and it is conditioned by the degree of atmospheric stability (Ross and Elliot, 1996, Spring, 2000). Vertical temperature variation is decreasing but in cases where the thermal gradient is negative it grows in upper layers (Ichim P. et al., 2014, Bărcăcianu F., Apostol L., 2014, Apostol et al., 2015, Fochesatto, 2015). In this situations thermal inversion phenomena occurs, which are generated by cold advections of continental air, intensified by radiative cooling during anticiclonic regime. The sheer magnitude of this phenomena leads to their expansion and intensification, occupying intra and extra areas in the Carpathian chain (Bogdan O., Niculescu E., 1999).

Orographic barrier of the Carpathians requires accumulation of cold and dense air (Apostol et al., 2015) and causes great intensity and frequency. Its thikness varies from 600-800 m, even from 1200 to 1300 m (Clima României, 2008), phenomena known as absolute, because its occupy all the concave space. Using data from aerological radiosounding results were observed in cold periods with atmospheric stability, multilayered temperature inversions and even upper level thermal inversion recorded at the upper end/superior base of boundary layer (Stull, 1988, Fochesatto, G. J. 2015). In 80\% of

\footnotetext{
${ }^{1}$ Alexandru Ioan Cuza University, 700505 Iasi, Romania, fbarcacianu@yahoo.com, istratevasile87@gmail.com

${ }^{2}$ Université de Lorraine, Laboratoire LOTERR-EA7304, 57045 Metz Cedex 01, France, roxana.bocancea@univ-lorraine.fr
} 
cases, thermal inversions act on the increasing values of the relative humidity. Thus, atmospheric visibility drops, fog phenomena occurs which maintains air pollutants on ground level (Croitoru A.E. et al, 2011, Wang, Li, Liu, \& Wu, 2010), the low level clouds increase, its height is given by top inversion layer (Horiguchi et al 2014).

\section{DATA AND METHODS}

The area examined includes extra and intra Carpathian territory from Romania bounded by $43^{\circ} 40^{\prime} \mathrm{N}$ to $48^{\circ} 11^{\prime} \mathrm{N}$ and from $20^{\circ} 19^{\prime} \mathrm{E}$ to $29^{\circ} 66^{\prime} \mathrm{E}$ with high vulnerability to thermal inversions imposed by morphology and morphometry of the terrain. For Romania the inversion phenomena were study by using data from National Meteorological Administration (N.M.A.) network or temperature sensors, and for free atmosphere were used radiosounding data for short periods.

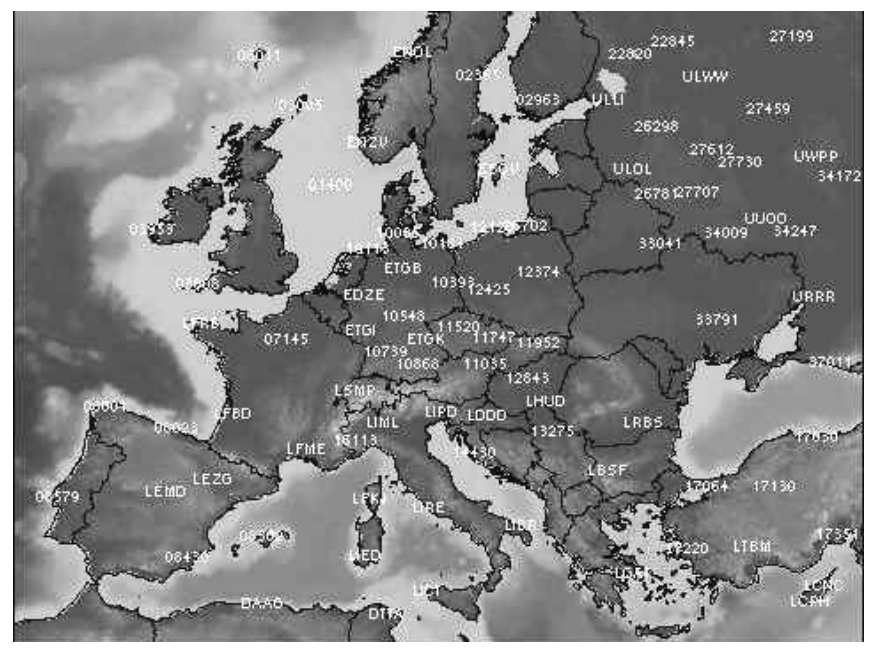

Fig.1. The European network of aerological stations

The database was compiled by using reanalysis data from the National Centers for Environmental Prediction / National Center for Atmospheric Research (NCEP/NCAR) and aerological soundings provided by Departament of Atmospheric Science, University of Wyoming. Data processing was performed with the CDO (Climate Data Operators) programs and with $\mathrm{R}$ soft script and the graphic material has been developed with Microsoft Excel, NumXL and XLSTAT extensions. With the raster layer from NCEP/NCAR, four significant pixels were extracted for Romania (Kalnay et al., 1996), with spatial resolution of $2.50 \times 2.50$, and quantifiable parameters of inversion phenomena and particular cases were analyzed by using aerological soundings at two national stations, Cluj-Napoca and Bucharest Băneasa, and two located in the neighbourhood of the Carpathian Mountains - Beograd and Odesa. Initial studies with significant results regarding atmospheric moisture in the lower layers of free atmosphere (850, 700 and 500 $\mathrm{hPa}$ ) materialized in 1954 in a relative humidity distribution maps by Telegadas and London and were subsequently completed by results for long periods by Oort A.H., Rsmusson E.M., al, 1992 . The analized period is bounded by 1979 and 2013 years and the methodology was done in accordance with the international methods, on four levels of 
absolute geopotential: 1000, 925, 850 and $700 \mathrm{hPa}$, for wich were extracted the altitude, temperature and relative humidity values.

\begin{tabular}{|c|c|c|c|c|}
\hline Aerological station & WMO Indicator & Altitude (m) & Latitude (degr) & Longitude (degr) \\
\hline Beograd & 13275 & 203 & 44,7 & 20,4 \\
\hline Bucharest -Băneasa & 15420 & 91 & 44,5 & 26,1 \\
\hline Cluj-Napoca & 15120 & 413 & 46,7 & 23,6 \\
\hline Odesa & 33837 & 42 & 46,4 & 30,8 \\
\hline
\end{tabular}

Table 1. The location of aerological stations in the analysis area

The applied climatic indexes were carried out on the values of temperature gradients calculated accoding to the formula $\mathrm{y}=\Delta \mathrm{T} / \Delta \mathrm{H}^{*} 100$ where $\Delta \mathrm{T}$ is the temperature differenceon altitude and $\Delta \mathrm{H}$ is altitude difference on absolutefrequency of negative values of thermal gradient.

\section{THE ANALYSIS OF THE PHENOMENA}

Spatial extension of absolute thermal inversions cover the whole intra- (Cluj-Napoca) and extracarpathian area (Beograd, Bucharest-Băneasa and Odesa), with regional differences imposed by the Carpathian chain (Apostol L., Sfícă L., 2013), but also by the particularities of the atmospheric circulation pattern.

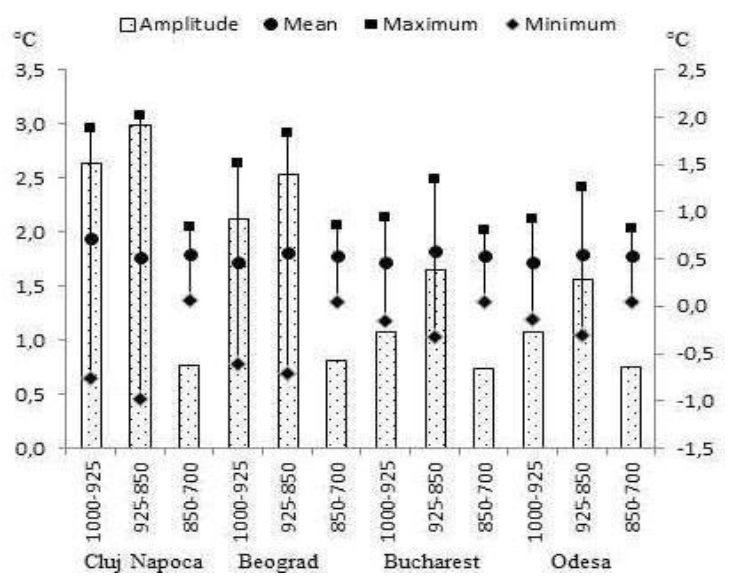

Fig. 2. The variation of amplitude, mean, maximum and minimum values of thermal gradients at Cluj-Napoca, Beograd, Bucharest Băneasa and Odesa aerological stations in the 1979-2013 period

The distribution of statistical descriptive indicators of thermal gradients show a high variability in first two layer caused by the thermal and dynamic processes of planetary boundary layer, with a maximum amplitude between 1,7 and $3^{\circ} \mathrm{C}$ calculated for $\mathrm{TR}_{925-850 \text {, }}$ fallowed by secondary values, 1,2 to $2,7^{\circ} \mathrm{C}$ on $\mathrm{TR}_{1000-925}$. The maximum and minimum values of thermal gradients fallow the same distribution in all analysed stations. 
Table 2. The monthly average frequency of negative thermal gradients under $700 \mathrm{hPa}$ at ClujNapoca, Beograd, Bucharest Băneasa and Odesa aerological stations in the 1979-2013 period

\begin{tabular}{|c|c|c|c|c|c|c|c|c|c|c|c|c|}
\hline \multirow{2}{*}{ Month } & \multicolumn{3}{|c|}{ Cluj-Napoca } & \multicolumn{3}{|c|}{ Beograd } & \multicolumn{3}{|c|}{ Bucharest Băneasa } & \multicolumn{3}{|c|}{ Odesa } \\
\hline & \begin{tabular}{|c|} 
TR \\
$1000-925$
\end{tabular} & TR & TR & TR & \begin{tabular}{|c|} 
TR \\
$925-850$ \\
9
\end{tabular} & $\begin{array}{c}\text { TR } \\
850-700\end{array}$ & $\begin{array}{c}\text { TR } \\
1000-925\end{array}$ & \begin{tabular}{|c|} 
TR \\
$925-850$
\end{tabular} & \begin{tabular}{|c|} 
TR \\
$850-700$
\end{tabular} & $\begin{array}{c}\text { TR } \\
1000-92\end{array}$ & \begin{tabular}{|c|} 
TR \\
$925-850$
\end{tabular} & TR \\
\hline I & 12.7 & 37.2 & 0.2 & 23.0 & $\mid 19.2$ & 0.5 & 2.9 & 6.5 & 0.3 & 2.9 & 6.5 & 0.3 \\
\hline II & & 22.9 & 0.1 & 17.0 & & 0.1 & & & & & & .2 \\
\hline III & 1.6 & 4.6 & 0.0 & 5.6 & 10.7 & 0.1 & 2. & 5.6 & 0.2 & 2.4 & 5.6 & 0.2 \\
\hline IV & & & & & & 0.0 & & & & & & 0.0 \\
\hline $\mathrm{V}$ & 0.0 & 0.0 & 0.0 & 0.0 & 0.0 & 0.0 & 1. & 0.0 & 0.0 & 1.0 & 0.0 & 0.0 \\
\hline & & & 0.0 & & 0.0 & 0.0 & & & & 0.1 & 0.0 & 0.0 \\
\hline VII & 0.0 & 0.0 & 0.0 & 0.0 & 0.0 & 0.0 & 0. & 00 & 00 & 0.0 & 0.0 & 0.0 \\
\hline & & & 0.0 & & 0.0 & 0.0 & & & & 0.0 & 0.0 & 0.0 \\
\hline IX & 0.0 & 0.0 & 0.0 & 0.0 & 1.1 & 0.1 & 0 & 06 & 00 & 0.0 & 0.6 & 0.0 \\
\hline $\mathbf{X}$ & 0.0 & 0.0 & 0.0 & 0.0 & 0.1 & 0.0 & & & 0.0 & 0.0 & 0.1 & 0.0 \\
\hline & & 23.6 & 0.1 & 13.5 & 19.3 & 0.1 & & & & 1.5 & 5.9 & 0.0 \\
\hline XII & 12.1 & 38.1 & 0.1 & 21.4 & 19.8 & 0.1 & 2.1 & 5.6 & 0.0 & 2.1 & 5.6 & 0.0 \\
\hline
\end{tabular}

Distribution of monthly average frequency of negative gradients registered periods of high atmospheric stability emerging from September to March, with the main peak in January at the first layer $\mathrm{TR}_{1000-925}$ and above it at $\mathrm{TR}_{850-700}$ (Tab. 2). Secondary peaks were recorded in December and February. The explanation lies in the manifestation of thermal inversions both on ground level and above it in winter months because cold advection leads to the accumulation of continental and radiative cooling of the air.

\section{RELATIVE HUMIDITY AND ABSOLUTE THERMAL INVERSIONS}

The regime of relative humidity registers a decrease in altitude, significant changes in the data being generated by a degree of stability or instability of the atmosphere. The lower troposphere holds the record higher values (Ross \& Elliott, 1996), the maximum being placed around $700 \mathrm{hPa}$ absolute geopotential. Thermal inversions leading to the acuumulation of water vapour under the lower base, a decreases in atmospheric visibility and the occurrence of the phenomena of fog, lower stratiforme clouds, weather phenomena with higher impact on air transport safety (Machidon D. et al., 2014).

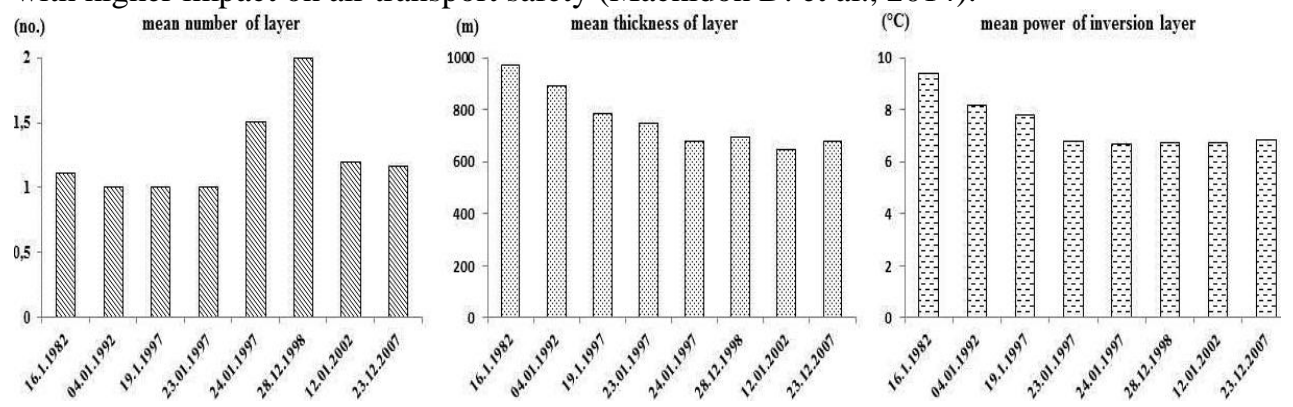

Fig.3. The distribution of quantifiable parameters: mean number, mean thickness, mean power of layer inversions at aerological stations Cluj-Napoca, Beograd, Bucharest Băneasa and Odesa in cases with absolute thermal inversion phenomena 
Of the total number of cases registered at relative geopotential ( $\mathrm{TR}_{1000-925}, \mathrm{TR}_{925-850}$, $\mathrm{TR}_{850-700}$ ) were selected only eight days with negative thermal gradients under $850 \mathrm{hPa}$ at all four aerological stations analysed, respectively: 16 January 1982, 04 January 1992, 19, 23,24 January 1997, 28 December 1998, 12 January 2002 and 23 December 2007.

The analysis of this phenomena was conducted using aerological data. Thus it was calculated the average cases, thickness and power layers with negative thermal gradient (Borşan D., 1981), the values fallowing the same trend at all four stations vertically. The results framed the phenomena recorded in the seven high risk class (Bogdan O., Niculescu E., 1999). The thermal amplitude of more than $6^{\circ} \mathrm{C}$, thickness of $800 \mathrm{~m}$ (Fig. 2), included entirely of spaces below the mean altitude of Carpathian chain and vertical expansion is based on the ground level except in 1997 and 1998, when were detected multiple layers of thermal inversions. The regime of relative humidity in lower troposphere depended on atmospheric circulation and on air advections particularities, the maximum values being caused by mediterranean air masses outside of the Carpathians and inside by humid oceanic air masses. (Clima României, 2008).
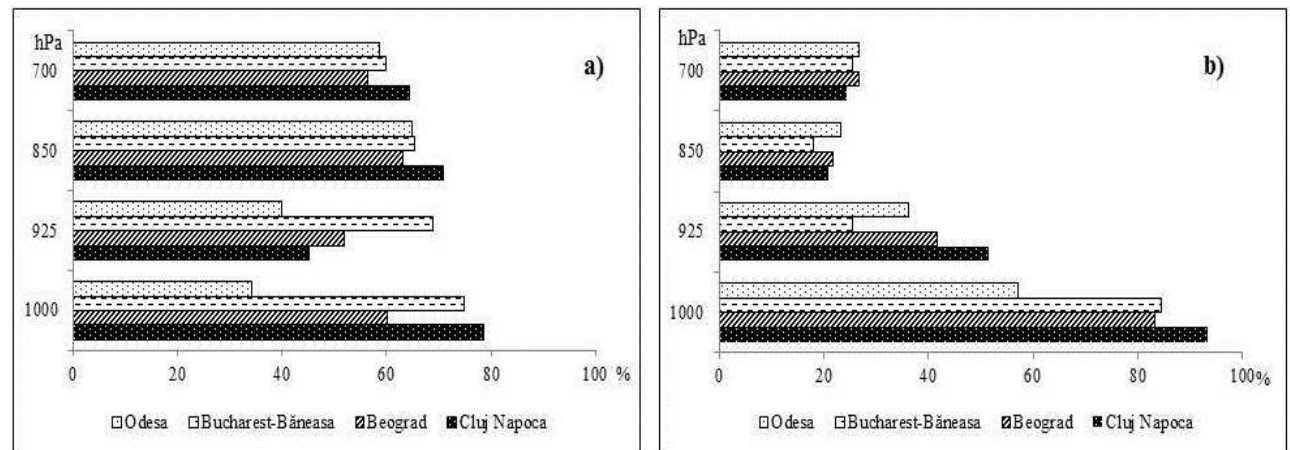

Fig.4. The distribution of mean values of relative humidity in lower troposphere at ClujNapoca, Beograd, Bucharest Băneasa and Odesa aerological stations in 1979-2013 (a) and in cases with absolute thermal inversion phenomena (b)

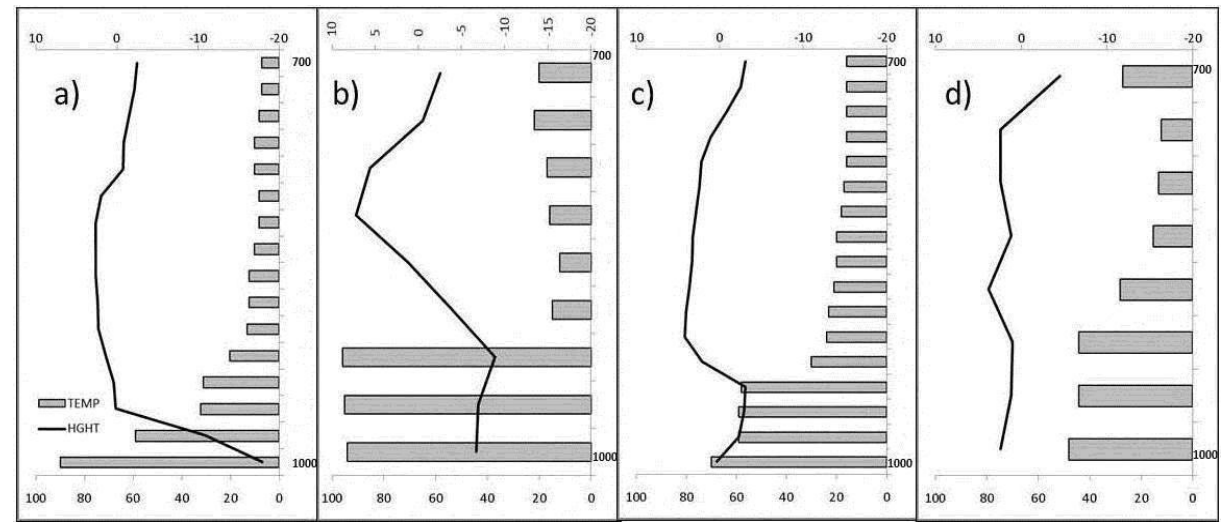

Fig.5. The variations of relative humidity and air temperature at Cluj-Napoca (a), Beograd (b), Bucharest-Băneasa (c) and Odesa (d) aerological stations in 16 January 1982 
The high variation of the mean annual values of relative humidity in altitude (see fig. no 4-a) reveal the particularities of regional climate in the areas represented by the four chosen stations. For the manifestation of absolute thermal inversion phenomena, verticaly it can be noticed an increase in the distribution of mean values, especially in the planetary boundary layer, under $850 \mathrm{hPa}$ (see fig. no. 4-b). The maximum of 1000 and $925 \mathrm{hPa}$ has higher values by more than $10 \%$ than the mean for the analysed period.

The detailed analysis of the most powerful absolute thermal inversions, in 16 January 1982 was performed using data from aerological soundings at 00 UTC (Fig.5). The vertical distribution of the two elements indicates agglomeration of the vapor water in the inversion layer (Spring S., 2000), where it is recorded the highest rate of relative humidity, of over $50 \%$ at Odesa, $60 \%$ at Bucharest Băneasa and over $80 \%$ at Beograd and Cluj-Napoca.

\section{CONCLUSIONS}

In the 1979-2013 period in the lower troposphere above Romania, under $700 \mathrm{hPa}$ geopotential surface occurred numerous thermal inversion phenomena, generated by the anticyclone regime.

Through the methodology applied were discovered eight individual cases in which there were negative gradients simultaneously in the case of the four stations below $850 \mathrm{hPa}$. The minimum temperature registered high records in some meteorological stations in Romania, among which $-29,3^{\circ} \mathrm{C}$ in January 1982 at Satu Mare and $-34,5^{\circ} \mathrm{C}$ at Întorsura Buzăului in December 1998 coinciding with two of the cases analysed.

In the cold season were recorded the lowest values of vertical thermal gradients and high levels of relative humidity as a result of thermal inversions at ground level or regime changes in altitude on distribution of water vapour in the lower layers.

\section{REFERENCES}

Apostol, L., Bărcăcianu, F., Ichim, P., Sfîcă, L. (2015) The thermal inversion phenomena on ground level and in the free atmosphere in the first $3000 \mathrm{~m}$. Advances in Environmental Sciences International Journal of the Bioflux Society, 7 (2), 196-204.

Apostol L., Sfică L. (2013) Thermal differentiations induced by the Carpathian mountains on the Romanian territory. Carpathian Journal of Earth and Environmental Sciences, Vol. 8, 215-221.

Bărcăcianu F., Apostol L., (2014), Considerations on temperature inversions in the lower troposphere in the 2001-2002 cold season, south of the Carpathian Mountains. PESD, Vol 8, no.2, 243-253.

Bărcăcianu F., Sîrghea L., Iordache I., Apostol L., Sfîcă L., (2015), Recent changes in air temperature in extra-carpathian Moldavia, Energy and clean technologies Conference proceedings, $15^{\text {th }}$ International Multidisciplinary Scientific Geoconference SGEM 2015, Albena, Bulgaria.

Bogdan O., Niculescu E., 1999, Riscurile climatice din România, Editura Academiei Române, Bucureşti.

Borşan D., (1981), Fizica atmosferei, Editura Universitatea Bucureşti, 252 p.

Croitoru Adina-Eliza, Holobâcă Iulian-Horia, Rus Ioan, Muresan Tatiana, (2011), Multivariate statistical analysis of fog phenomenon in northwestern Romania, Geographia Technica, No.1, pp.9-19 
Fochesatto, G. J. (2015). Methodology for determining multilayered temperature inversions. Atmospheric Measurement Techniques, 8(5), 2051-2060. doi:10.5194/amt-8-2051-2015.

Horiguchi M., Hayashi T., Adachi A., Onogi S., (2014) Stability dependence and d iurnal c hange of large-scale turbulence structures in the near-neutral atmospheric boundary layer observed from a meteorological tower. Boundary Layer Meteorol. 151(2):221-237.

Ichim P., Apostol L., Sfîcă L., Kadhim-Abid A.L., Istrate V., (2014), Frequency of thermal inversions between Siret and Prut rivers in 2013, PESD, Vol 8, no.2, p 267-284.

Kalnay E., Kanamitsu M., Kistler R.,Collins W.,Deaven D., Gandin L.,Irredel M., Saha S., White J., Woollen J., Zhun Y., Chelliah M., Ebisuzaki W., Leetmaa A., Reynolds R., Jenne Roy, Joseph D., (1996), The NCEP/NCAR 40 year realanalysis project. Bulletin of the American Meteorological Society, doi: http://dx.doi.org/10.1175/15200477(1996)077<0437:TNYRP>2.0.CO;2.

Machidon D., Apostol L., Buruiană D., (2014), Considerations of the fog regime in the airports area fron Moldavia territory (Romania), Aerul şi Apa. Componente ale Mediului, p. 142-149.

Oort A.H., Rsmusson E.M., (1972), Atmospheric Circulation Statistic, Natl. Oceanogr. and Atmos , Washington D.C.

Peixoto, J. P., \& Oort, a. H. (1996). The climatology of relative humidity in the atmosphere. Journal of Climate. Vol. 9, Issue 12, doi:10.1175/1520-0442

Ross, R. J., \& Elliott, W. P. (1996). Tropospheric Water Vapor Climatology and Trends over North America: 1973-93. Journal of Climate. doi:10.1175/15200442(1996)009<3561:TWVCAT>2.0.CO;2.

Spring, S. (2000). Radiosonde-Based Northern Hemisphere Tropospheric Water Vapor Trends, $1602-1612$.

Stull R.B., (1988), An introduction to boundary layercmeteorology, Kluwer academic publishers, $655 \mathrm{p}$.

Suparta Wayan, 2011, Monitoring of GPS PWV association to the solar energetic events during the intense solar flares of october/november 2003, Geographia Technica, No.1, 2011, 72-81 pp.

Telegadas K., London J., (1954), A physical model of Northen Hemisphere troposphere for winter and summer. Scientific Report, No. 1, Research Div. College of Engineering, New York University, 55p.

Trenberth, K. E., \& Guillemot, C. J. (1998). Evaluation of the atmospheric moisture and hydrological cycle in the NCEP / NCAR reanalyses.

Wang, J. L., Li, S. M., Liu, X. L., \& Wu, X. J. (2010). An analysis of the fog distribution in Beijing for the 2001-2005 period using NOAA and FY data. Atmospheric Research, 96(4), 575-589. doi:10.1016/j.atmosres.2010.01.007.

Wyngaard, J. C., Pennell, W. T., Lenschow, D. H., LeMone, M. a. (1978). The Temperature-Humidity Covariance Budget in the Convective Boundary Layer. Journal of the Atmospheric Sciences. doi:10.1175/1520-0469 